connexion of various elements with consequent saving of comploxity and space. The machine has the rather large number of 50 integrators, which gives it great power and versatility, its physical size is quite small - about $20 \mathrm{c}$. ft.- and its appearance is attractive and neat. When it is produced in quantity, it should prove an invaluable research tool in universities, colleges of technology and in industry. It is pleasant to see that Britain has now entered this important new field.

Imperial Chemical Industries, Ltd.

A NEW ammonia plant, with a capacity of 100,000 tons a year, and associated plants to make urea and fertilizers is to be built at Imperial Chemical Industries, Ltd., Severnside Works in south Gloucestershire, at a cost of upwards of $£ 10$ millions. This plant is expected to start production during 1963. This is the second important project that Imperial Chemical Industries has decided to construct on the new 1,000-acre Severnside site. The first, announced in February, will involve the construction of plants to make ethylene oxide and ethylene glycol, costing $£ 5$ millions. Imperial Chemical Industries has also decided to extend the methanol plant at its Heysham Works in Lancashire. A new plant to make 30,000 tons a year began production there only a few months ago. A further extension to make an additional 45,000 tons a year is now to be built, and is expected to be completed during 1962. Methanol is an important raw material for the plastics industry.

Scientific and Technical Services in Rhodesia and Nyasaland

A IIst has recently been published of government and statutory bodies concerned with scientific research and technical services in the Federation of Rhodesia and Nyasaland, giving in brief the history, functions, organization, location and establishment of each (Government Organizations and Statutory Bodies concerned with Scientific Research and Technical Services in the Federation of Rhodesia and Nyasaland, 1959. Pp. 80. Salisbury : Office of the Federal Prime Minister and External Affairs, 1959). Research within the Federation is treated as a "concurrent subject", that is to say, that both the Federal and Territorial Governments have power to legislate in this field. The Federal Government obtained the services of Mr. D. G. Kingwell, of the South African Council for Sciontific and Industrial Research, to report on the development of science in the Federation. Mr. Kingwell's recommendations have been adopted, and a Research Act has been brought into operation which is designed to promote scientific and. industrial research, including agricultural, veterinary and tsetse research, to establish a research foundation and to provide for the establishment of research councils.

\section{Organization of Medical Care}

A ReporT by a World Health Organization Committee on medical care embodies the opinion of a grc sp of experts from several countries, representing public health administration, hospital administration, medical practice, health insurance and voluntary agencies, on measures for "the organization and co-ordination of comprehensive preventive and curative medical care services provided to the individual outside the hospital wards" (World Health Organization. Technical Report Series No. 176: Role of Hospitals in Ambulatory and Domiciliary Medical
Care-Second Report of the Expert Committee on Organization of Medical Care. Pp. 32. (Geneva : World Health Organization; London : H.M. Stationery Office, 1959.) 1 Swiss franc; $1 s .9 d$.; 0.30 dollar.) The scope of such services is considered to cover ambulatory care in out-patient departments, domiciliary care, after-care and medical rehabilitation. While recognizing that the degree of co-ordination possible will depend on national or local conditions, the Committee considers that the establishment of a central authority with planning and advisory powers would facilitate the rational siting of services and maintain the standards of both the care given and the equipment available. The main out-patient services which would be expected to contribute to a programme of ambulatory and domiciliary medical care are defined, and their functions indicated. They are: dispensaries, polyclinics, out-patient departments, health centres, medical practitioners, industrial medical services, medical rehabilitation centres, and intermediate institutions such as day-hospitals and night hostels. It is emphasized that continuity of care is of the utmost importance; this involves provision for an easy transition from domiciliary and ambulatory to hospital care, and back to the physician first concerned with the case.

\section{The National Research Development Corporation of India}

THE fifth annual report and statement of accounts of the National Research Development Corporation of India covers the period ending March 31, 1959, and records sustained progress (pp. 23. New Delhi : National Research Development Corporation of India, 1959). Commercial production from several patents and processes licensed in previous years has already commenced and twenty-four licences were negotiated compared with seventeen in the previous year, and five processes went into production. Development expenditure on projects already sanctioned amounted to Rs. 3.91 lakhs, and gross income from premiums and royalties increased to Rs. 1.66 lakhs. Marketing of 'Hykol' brand activated carbons produced at the Regional Research Laboratory, Hyderabad, commenced, and mica insulating bricks and carbons produced by Corporation licencees have been used in the Bhilai steel plant. During the year 56 inventions were reported for development by 20 research institutions, bringing the total of reported inventions to 503. Projects for the refining of cotton seed oil and the production of copper chlorophyll from indigenous raw materials were completed, and progress is reported in the projects for phthalic anhydride, de-jonization of cane juice, white cement from feldspar, and the fluidized-bed technique for textile processing.

\section{Inventory of Economic Studies in Africa}

The Commission for Technical Co-operation in Africa South of the Sahara has issued an annotated reading list of books, articles and official publications since 1945 dealing with economics in Africa (CSA) CCTA Publication No. 30; Joint Project No. 4: Inventory of Economio Studies concerning Africa South of the Sahara-an Annotated Reading List of Books, Articles and Official Publications. Pp. $x i+301$. (London: Commission for Technical Co-operation in Africa South of the Sahara, 1960)). The inventory, which has been edited by Miss Peter Ady on the basis of information collected by a panel of national correspondents in economics, is the out- 